Proceedings

\title{
Comparative Antimicrobial Activity Study of Brassica oleceracea ${ }^{\dagger}$
}

\author{
Sandeep Waghulde *, Nilofar Abid Khan *, Nilesh Gorde, Mohan Kale, Pravin Naik and \\ Rupali Prashant Yewale
}

Konkan Gyanpeeth Rahul Dharkar College of Pharmacy and Research Institute, Karjat, Dist-Raigad, Pin code 410201, India; nileshgorde83@gmail.com (N.G.); kalemkpharm@gmail.com (M.K.); pravin.aazocom@gmail.com (P.N.); rupalikalp123@gmail.com (R.P.Y.)

* Correspondence: sandeepwaghulde@yahoo.com (S.W.); afnan.21@rediffmail.com (N.A.K.)

+ Presented at the 22nd International Electronic Conference on Synthetic Organic Chemistry, 15 November15 December 2018. Available Online: https://sciforum.net/conference/ecsoc-22.

Published: 14 November 2018

\begin{abstract}
Medicinal plants are in rich source of antimicrobial agents. The present study was carried out to evaluate the antimicrobial effect of plants from the same species as Brassica oleceracea namely, white cabbage and red cabbage. The preliminary phytochemical analysis was tested by using a different extract of these plants for the presence of various secondary metabolites like alkaloids, flavonoids, tannins, saponins, terpenoids, glycosides, steroids, carbohydrates, and amino acids. The in vitro antimicrobial activity was screened against clinical isolates viz gram positive bacteria Staphylococcus aureus, Streptococcus pyogenes, gram negative bacteria Escherichia coli, Pseudomonas aeruginosa. Extracts found significant inhibition against all the pathogens.
\end{abstract}

Keywords: plant extract; phytochemicals; antibacterial activity; antifungal activity

\section{Introduction}

Despite great progress in the development of medicines, infectious diseases caused by bacteria, fungi, viruses and parasites are still a major threat to public health. The impact is mainly observed in developing countries due to relative unavailability of medicines and the emergence of widespread drug resistance [1]. Plants are the richest source of natural antimicrobial agents. Traditional healers claim that some medicinal plants are more efficient to treat infectious diseases than synthetic antibiotics [2]. From ancient times, different parts of medicinal plants have been used to cure specific ailments [3]. Medicinal plants are widely used because of its easy availability and cost effectiveness. The active principles of many drugs found in plants are secondary metabolites. The antimicrobial activities of plant extracts may be found in a variety of chemical components, including aldehyde and phenolic compounds [4]. India is well known for Ayurveda, which is one of the important traditional medicines practiced. Herbs are widely exploited in the traditional medicine and their curative potentials are well documented [5].

Brassicaceae vegetables are a good source of food around the world. In the past, a diverse range of metabolites has been reported from this genus with regard to human nutrition. Extensive data is available on the biological activities of primary and secondary metabolites of Brassica plants, such as antioxidant, anticancer, and antimicrobial activity. Brassica oleracea var. capitata, Brassica oleracea var. botrytis, and R. sativus var. longipinnatus are the important species of Brassicaceae, these species are well known plant sources used as food as well as for plant research.

Brassicaceae or the Cruciferae family contains Brassica oleracea. This family is comprised of approximately more than 3400 described species distributed among 350 genera including 
cauliflower, broccoli, kohlrabi, kale, cabbage and Brussels sprouts. Many researchers have highlighted the potentials of Brassica species as a source of antibacterial [6-8] substances.

Red cabbage is the member of the Brassicaceae family. It is a cool season cruciferous vegetable. Red cabbage (Brassica oleracea var. capitataf. rubra) is type of cabbage, also well known as purple cabbage, blue kraut, or red kraut and is widespread in the Mediterranean region. Red Cabbage is a herbaceous, biennial, dicotyledonous flowering plant. Its leaves are red or purple in colour and are normally consumed as coleslaw, salad and beverage [9-11].

\section{Materials and Methods}

\subsection{Plant Materials}

Brassica oleracea var. capitataf. rubra leaves were collected in month of December 2016 from local market of karjat, District - Raigad, Maharashtra, India. The plants were identified and authenticated by a taxonomist.

Red cabbage leaves were shade dried followed by hot air oven drying at $50{ }^{\circ} \mathrm{C}$ and then ground to a fine powder and stored in airtight container for the analysis. Fresh red cabbage leaves were grinded in the mixer for the collection of juice.

\subsection{Preparation of Extracts}

A $5 \mathrm{~g}$ of crushed vegetable samples was added to three different flasks and extracted using $60 \%$ methanol, $60 \%$ ethanol or $60 \%$ acetone with 1-min nitrogen flushing at 20 psi. The concentration of solvent was decided on the basis of available literature (Zhao \& Hall, 2008; Cox et al., 2010). Flasks were kept in a shaking incubator (Innova 42, Mason Technology, Dublin, Ireland) at $100 \mathrm{rpm}$ and 40 ${ }^{\circ} \mathrm{C}$ for $2 \mathrm{~h}$. The infusions were filtered with Whatman $\# 1$ until a clear extract was obtained.

\subsection{Phytochemical Analysis}

\subsubsection{Qualitative Analysis}

Chemical tests were carried out on the Ethanol, Methanol, and aqueous, extracts using procedures to identify the phytochemicals as described by Sofowara [2], Trease and Evans3 and Harborne4[12-16].

\begin{tabular}{|c|c|c|}
\hline Test & Procedure & Observation \\
\hline Test for Carbohydrates & $\begin{array}{l}\text { To } 2 \mathrm{~mL} \text { of extract, } 1 \mathrm{~mL} \text { of Molisch's reagent } \\
\text { and few drops of concentrated sulphuric acid } \\
\text { were added. }\end{array}$ & $\begin{array}{l}\text { Formation of Purple colour at } \\
\text { the inter phase of the two } \\
\text { layers indicated the presence } \\
\text { of carbohydrates }\end{array}$ \\
\hline $\begin{array}{l}\text { Test for Amino acids and } \\
\text { Proteins }\end{array}$ & $\begin{array}{l}2 \mathrm{~mL} \text { of filtrate was treated with } 2-5 \text { drops of } \\
\text { ninhydrin solution placed in a boiling water } \\
\text { bath for } 1-2 \mathrm{~min} \text {. }\end{array}$ & $\begin{array}{l}\text { It was observed for the } \\
\text { formation of purple colour. }\end{array}$ \\
\hline Test for Tannins & $\begin{array}{c}\text { To } 1 \mathrm{~mL} \text { of extract, } 2 \mathrm{~mL} \text { of } 5 \% \text { ferric chloride } \\
\text { was added. }\end{array}$ & $\begin{array}{l}\text { Formation of greenish black } \\
\text { color indicated the presence } \\
\text { of tannins. }\end{array}$ \\
\hline Test for Saponins & $\begin{array}{c}\text { To } 2 \mathrm{~mL} \text { of extract, } 2 \mathrm{~mL} \text { of distilled water } \\
\text { was added and shaken in a graduated } \\
\text { cylinder for } 15 \mathrm{~min} \text { length wise. }\end{array}$ & $\begin{array}{l}\text { Formation of } 1 \mathrm{~cm} \text { layer of } \\
\text { foam indicated the presence } \\
\text { of saponins. }\end{array}$ \\
\hline Test for Flavonoids & $\begin{array}{c}5 \mathrm{~mL} \text { of dilute ammonia solution was added } \\
\text { to a portion of the aqueous filtrate of extract } \\
\text { followed by addition of concentrated } \\
\text { sulphuric acid. }\end{array}$ & $\begin{array}{l}\text { Appearance of yellow color } \\
\text { indicated the presence of } \\
\text { flavonoids }\end{array}$ \\
\hline $\begin{array}{l}\text { Test for Alkaloids } \\
\text { Mayer's Test }\end{array}$ & $\begin{array}{l}\text { To } 2 \mathrm{~mL} \text { of extract, } 2 \mathrm{~mL} \text { of concentrated } \\
\text { hydrochloric acid was added. Then few drops } \\
\text { of Mayer's reagent were added. }\end{array}$ & $\begin{array}{l}\text { Presence of white precipitate } \\
\text { indicated the presence of } \\
\text { alkaloids }\end{array}$ \\
\hline
\end{tabular}




\begin{tabular}{|c|c|c|}
\hline Wagner's test & $\begin{array}{c}\text { To a few mL of filtrate, few drops of Wagner's } \\
\text { reagent were added by the side of the test } \\
\text { tube. }\end{array}$ & $\begin{array}{l}\text { A reddish -brown precipitate } \\
\text { confirmed the test as positive. }\end{array}$ \\
\hline $\begin{array}{l}\text { Test for Anthocyanin and } \\
\text { Betacyanin }\end{array}$ & $\begin{array}{l}\text { To } 2 \mathrm{~mL} \text { of extract, } 1 \mathrm{~mL} \text { of } 2 \mathrm{~N} \text { sodium } \\
\text { hydroxide was added and heated for } 5 \mathrm{~min} \text { at } \\
100^{\circ} \mathrm{C} \text {. }\end{array}$ & $\begin{array}{l}\text { Formation of yellow color } \\
\text { indicated the presence of } \\
\text { betacyanin. }\end{array}$ \\
\hline Test for Quinones & $\begin{array}{c}\text { To } 1 \mathrm{~mL} \text { of extract, } 1 \mathrm{~mL} \text { of concentrated } \\
\text { sulphuric acid was added. }\end{array}$ & $\begin{array}{c}\text { Formation of red color } \\
\text { indicated the presence of } \\
\text { quinones }\end{array}$ \\
\hline Test for Glycosides & $\begin{array}{l}\text { To } 1 \mathrm{~mL} \text { of the extract add few drops of } \mathrm{HCl} \text {, } \\
\text { allowed for } 5 \mathrm{~min} \text { for hydrolysis and } \\
\text { neutralized with } \mathrm{NaOH} \text { solution. A few drops } \\
\text { of Fehling's solution } \mathrm{A} \text { and } \mathrm{B} \text { are added and } \\
\text { heated for few minutes. }\end{array}$ & $\begin{array}{l}\text { An orange red precipitate } \\
\text { indicates the presence of } \\
\text { glycosides. }\end{array}$ \\
\hline Test for Terpenoids & $\begin{array}{l}\text { To } 0.5 \mathrm{~mL} \text { of extract, } 2 \mathrm{~mL} \text { of chloroform was } \\
\text { added and concentrated sulphuric acid was } \\
\text { added carefully. }\end{array}$ & $\begin{array}{l}\text { Red brown color formation at } \\
\text { the interface indicated the } \\
\text { presence of terpenoids. }\end{array}$ \\
\hline Test for Phenols & $\begin{array}{l}\text { To } 1 \mathrm{~mL} \text { of the extract, } 2 \mathrm{~mL} \text { of distilled water } \\
\text { followed by few drops of } 10 \% \text { ferric chloride } \\
\text { was added. }\end{array}$ & $\begin{array}{l}\text { Formation of greenish black } \\
\text { color indicated the presence } \\
\text { of phenols. }\end{array}$ \\
\hline Test for Coumarins & $\begin{array}{c}\text { To } 1 \mathrm{~mL} \text { of extract, } 1 \mathrm{~mL} \text { of } 10 \% \text { Sodium } \\
\text { hydroxide was added. }\end{array}$ & $\begin{array}{l}\text { Formation of yellow color } \\
\text { indicated the presence of } \\
\text { coumarins. }\end{array}$ \\
\hline $\begin{array}{l}\text { PhytosterolLibermann- } \\
\text { buchard's test: }\end{array}$ & $\begin{array}{l}\text { The extract }(50 \mathrm{mg}) \text { was dissolved in } 2 \mathrm{~mL} \\
\text { acetic acid anhydride. To this, one or two } \\
\text { drops of concentrated sulphuric acid were } \\
\text { added slowly along the side of the test tube. }\end{array}$ & $\begin{array}{l}\text { An array of color changes } \\
\text { showed the presence of } \\
\text { phytosterols. }\end{array}$ \\
\hline Salkowski's test & $\begin{array}{c}\text { The extract was treated with Salkowski's } \\
\text { reagent }\end{array}$ & $\begin{array}{l}\text { The yellowish colour with } \\
\text { green fluorescence } \\
\text { appearance indicated the } \\
\text { presence of phytosterol in it. }\end{array}$ \\
\hline
\end{tabular}

\subsubsection{Quantitative Analysis}

\section{Estimation of Total Proteins}

Total protein in the plant extracts was determined using the colorimetric method described by O.H. Lowry, et. al., (1951) [5]. Plant extract $(0.4 \mathrm{~mL})$ was then mixed with $4 \mathrm{~mL}$ of copper sulphate solution and incubated at room temperature for $10 \mathrm{~min}$. Then, $4 \mathrm{~mL}$ of phenol reagent was allowed to react for $30 \mathrm{~min}$. The absorbance was measured at $600 \mathrm{~nm}$ against reagent blank. Bovine serum albumin $(1 \mathrm{mg} / \mathrm{mL})$ was used as standard and then $15,30,60,90,120$ and $150 \mu \mathrm{g}$ were taken from the standard solution and these readings were used to calculate the total amount of proteins.

\section{Estimation of Total Sugars}

The total sugar in the plant extract was determined by M. Dubois, et. al., (1956) [6]. Plant extract $(1 \mathrm{~mL})$ was mixed with $1 \mathrm{~mL}$ of $2 \%$ phenol and $5 \mathrm{~mL}$ of concentrated sulphuric acid, allowed to react for $30 \mathrm{~min}$ and absorbance was measured at $430 \mathrm{~nm}$ against reagent blank. For total sugar estimation glucose $(1 \mathrm{mg} / \mathrm{mL})$ was used as a standard and then $20,40,60,80,100 \mu \mathrm{g}$ were taken from the standard solution and readings were used to know the total sugars present in extraction samples. Antimicrobial activity is done by disc plate method. Authenticed pure cultures of bacterias namely; Escherichia coli, Bacillus subtilis, Candida Albicans, Psudomonas. Vulgeris and Aspergilus Niger were collected. 
Nutrient Agar preparation:

\section{Ingredients:}

1. $0.5 \%$ Peptone - this provides organic nitrogen

2. $0.3 \%$ beef extract/yeast extract-the water-soluble content of these contribute vitamins, carbohydrates, nitrogen, and salts

3. $1.5 \%$ agar - this gives the mixture solidity

4. $0.5 \%$ Sodium Chloride-this gives the mixture proportions similar to those found in the cytoplasm of most organisms

5. Distilled water-water serves as a transport medium for the agar's various substances

6. $\mathrm{pH}$ adjusted to neutral $(6.8)$ at $25^{\circ} \mathrm{C}$.

\section{Preparation:}

These ingredients are combined and boiled for approximately one minute to ensure they are mixed and to sterilize them. Then they are cooled to around $50{ }^{\circ} \mathrm{C}\left(122{ }^{\circ} \mathrm{F}\right)$ and poured into Petri dishes thatare covered immediately. Once the dishes hold solidified agar, they are stored in refrigerated until used.

\section{Procedure (Cup and Plate method)}

1. Nutrient agar is poured into Petri dishes and allowed to solidify.

2. Then bacterial culture is spread on the plate.

3. Allow it settle for $10 \mathrm{~min}$.

4. With the help of borer (6 mm diameter) two wells are prepared; marked it A and B

5. Sample solution A and B are prepared, about $1 \mathrm{~mL}$ is poured in respectively.

6. Allow it to stand for $15 \mathrm{~min}$.

7. Then incubate it in incubator for $24 \mathrm{~h}$.

8. Measure the zone by using antibiotic zone reader.

\section{Minimum inhibitory concentration (MIC):}

Purple cabbage extract solution was diluted with ethanol to $4,2,1,0.5,0.25 \mathrm{mg} / \mathrm{mL}$, in sterile Petri dishes were added to $1 \mathrm{~mL}$ of different concentrations of diluents then poured into $20 \mathrm{~mL}$ culture medium, mixed thoroughly, after cooling and solidification take $1.1 \mathrm{~mL}$ ( 0.5 the McIntosh turbidity) of the test bacterial suspension, observed in an incubator for $24 \mathrm{~h}$, each repeated three times, take average [10].

\section{Result and Discussion}

In the present study the comparison between the phytochemical property of red cabbage powder and juice were estimated. The preliminary phytochemical investigation on red cabbage powder and juice extracts revealed the presence of various secondary metabolites such as alkaloids, glycosides, steroids, flavonoids, saponnin, tannin, terpenoids and phytosterols in the different extracts (Tables 1 and 2).

There was a significant difference in the activity of the Methanolic extracts on the individual standard strains studied (Table 3). A mild inhibition with mean zones of $13.1 \mathrm{~mm}, 11.7 \mathrm{~mm}, 13.9 \mathrm{~mm}$ $12.9 \mathrm{~mm}$ and $11.4 \mathrm{~mm}$ for, respectively were recorded. Inhibitory activity was the same for S. Enteritidis 13,076 and S. aureus 29,213 on separation of treatment means. The highest growth inhibition was observed on S. aureus and lowest on E. coli strains. 
Table 1. Preliminary Phytochemical Screening of Red Cabbage Powder Extract.

\begin{tabular}{ccc}
\hline Name of the Chemical test & Methanol Extract & Distill Water Extract \\
\hline Alkaloids & Present & Present \\
Gylcosides & Absent & Present \\
Steroids & Present & Present \\
Flavonoids & Present & Present \\
Saponin & Absent & Present \\
Tannin & Present & Present \\
Terpenoids & Absent & Present \\
Phytosterols & Present & Present \\
\hline
\end{tabular}

Table 2. Quantitative analysis of Proteins and Sugars.

\begin{tabular}{|c|c|c|c|}
\hline Botanical Name & Extract & $\begin{array}{c}\text { Total Protein } \\
(\mu \mathrm{g}) / \mathrm{mg} \text { of Extract }\end{array}$ & $\begin{array}{c}\text { Total Sugar } \\
(\mu \mathrm{g}) / \mathrm{mg} \text { of Extract }\end{array}$ \\
\hline \multirow{2}{*}{$\begin{array}{c}\text { Brassica oleracea Brassica } \\
\text { oleracea var. capitataf. rubra }\end{array}$} & $\begin{array}{c}\text { Methanolic } \\
\text { extract }\end{array}$ & $165 \pm 1.46$ & $472 \pm 1.24$ \\
\hline & $\begin{array}{l}\text { Distill water } \\
\text { extract }\end{array}$ & $52.3 \pm 1.21$ & $87 \pm 2.21$ \\
\hline
\end{tabular}

${ }^{*}$ Each value is presented as mean \pm S.D. $(n=3)$.

Table 3. Comparative study of antibacterial activities of Red Cabbage.

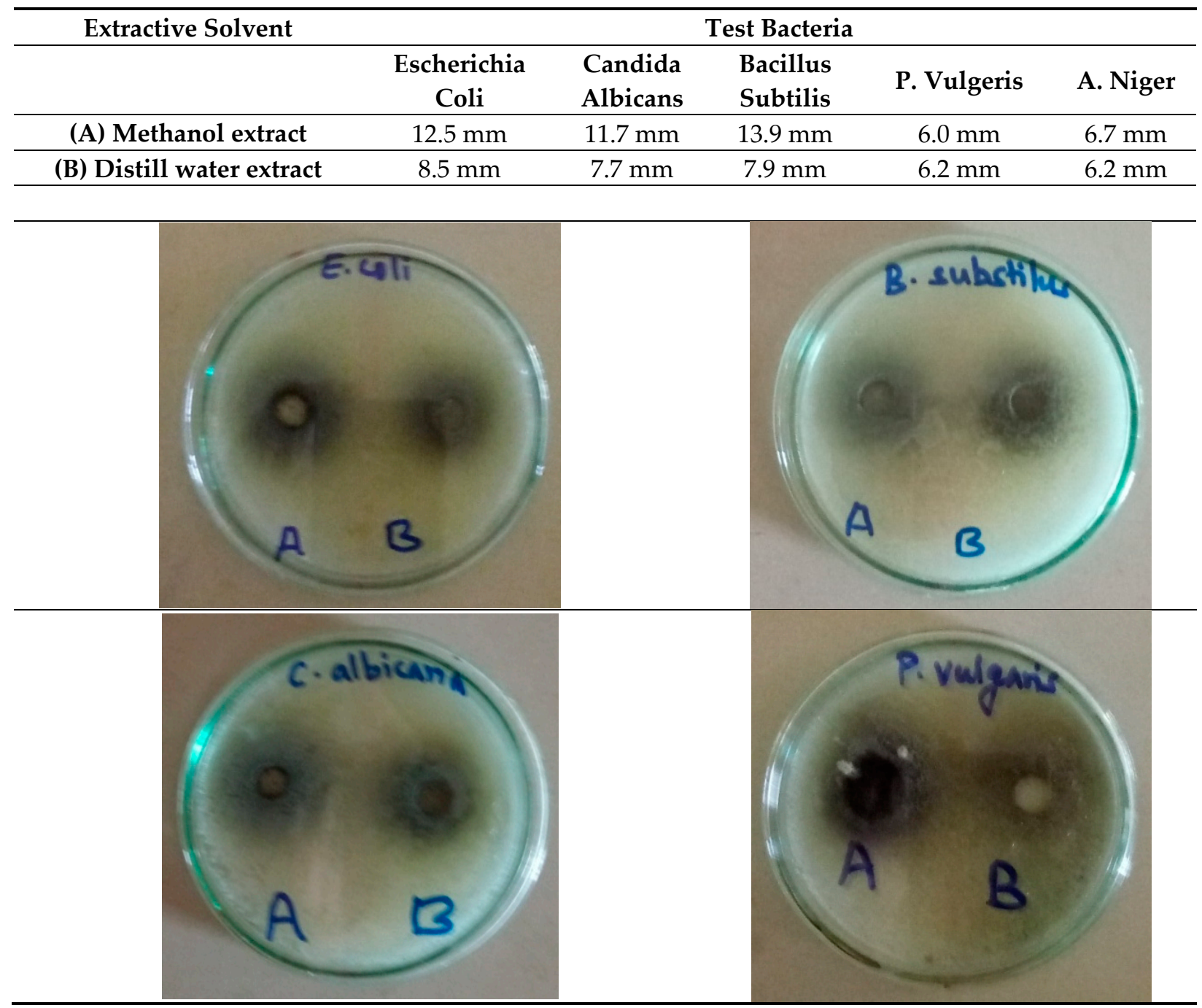




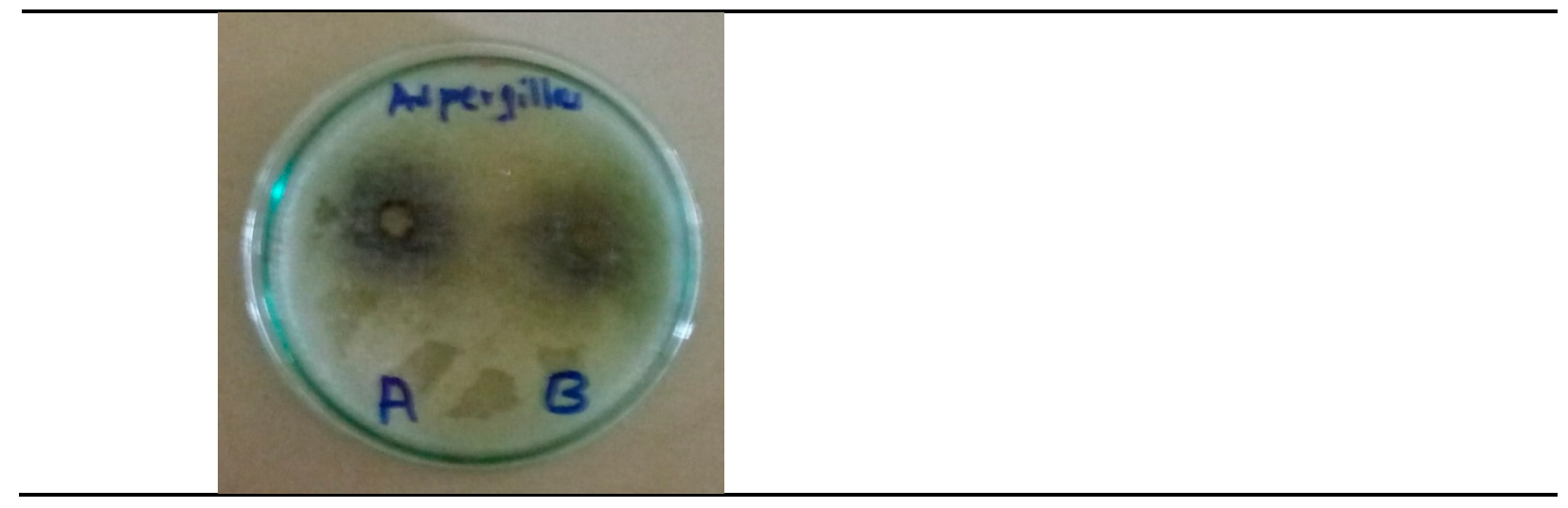

\section{Discussion}

The present study was carried out on the plant extract to reveal the presence of medicinally active constituents such as carbohydrates, amino acids, tannins, flavonoids, alkaloids, phenols, terpenoids, quinines, proteins, and coumarins in most of the plants, which could be responsible for the observed antimicrobial property (summarized in Table 1). Flavonoids are hydroxylated phenolic substances known to be synthesized by plants in response to microbial infection and they have been found in vitro to be effective antimicrobial substances against a wide array of microorganisms. In the present study, the agar disc diffusion method was used to evaluate the antimicrobial activity by measuring the inhibition zone against the test microorganisms. The results obtained by various extracts of Brassica oleracea var. capitata showed that ethanol extracts exhibited prominent antibacterial activity against Escherichia coli, Bacillus subtilis, Candida Albicans, Psudomonas Vulgeris and Aspergilus Niger. Out of these extracts ethanol extracts showed that maximum inhibition zones against test organisms. These studies suggested that ethanol extracts of the plant leaves provide broad range antimicrobial activity against such organisms.

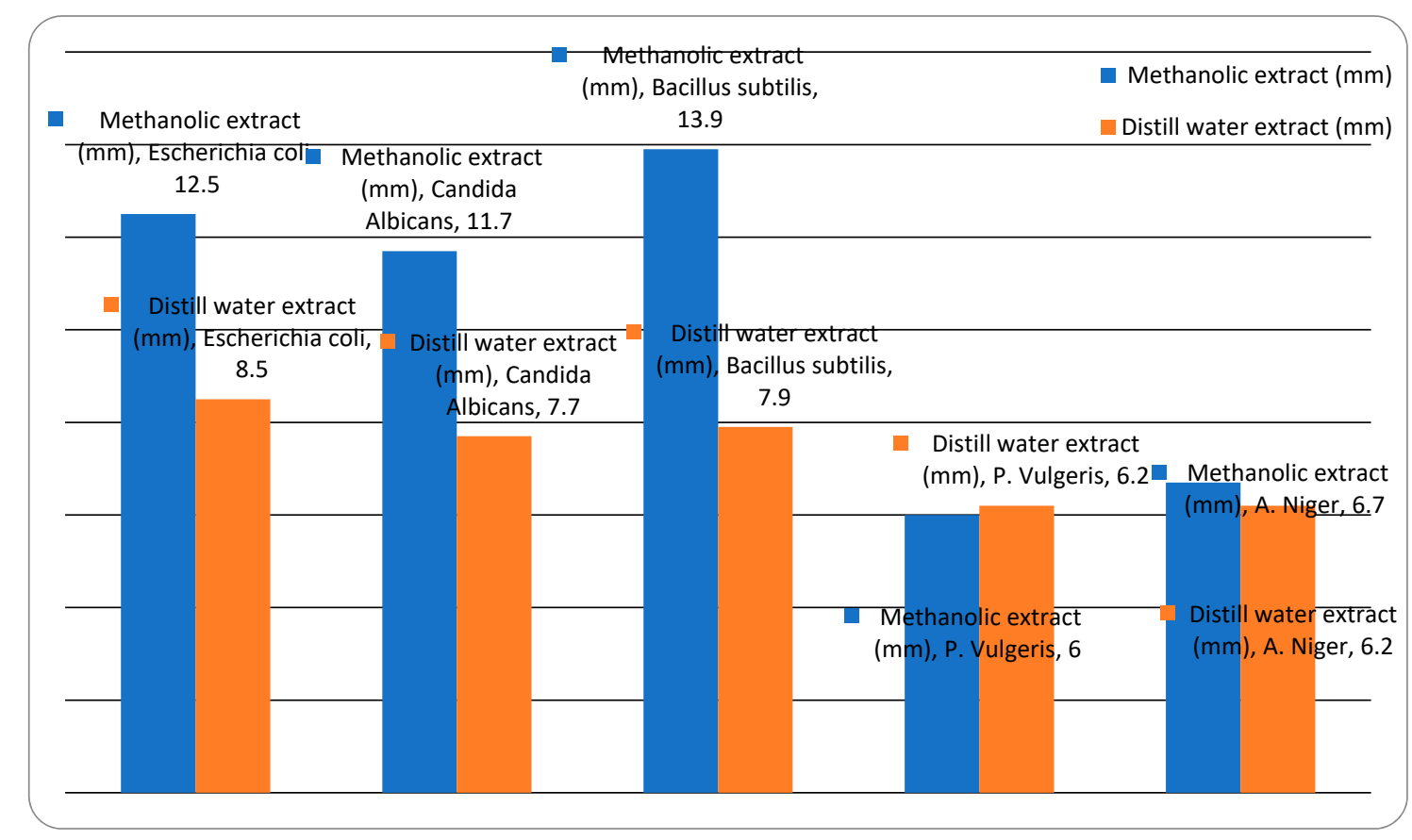

Figure 1. Antimicrobial activity.

\section{Conclusions}

The present study reveals that the ethanol extracts of these vegetables possess a number of secondary metabolites and also shows antimicrobial activity. Out of which the methanol extract of cabbage showed the highest inhibitory activity against Bacillus subtilis. Antimicrobial activity of the 
above plants proved that ethanol is the most effective solvent for extracting broad spectrum of antimicrobial compounds from plant origin. Antimicrobial nature of these plants could be useful to improve natural antimicrobial drugs from vegetables.

Acknowledgments: The authors acknowledge to Mohan Kale, Principal KGRDCP \& RI Karjat College for providing platform for this work and thanks to the Department of Biotechnology for supporting to carry out this work.

\section{References}

1. Zampini, I.C.; Cuello, S.; Alberto, M.R.; Ordóñez, R.M.; D’almeida, R.; Solorzano, E.; Isla, M.I. Antimicrobial activity of selected plant species from "the Argentine Puna" against sensitive and multi-resistant bacteria. J. Ethnopharmacol. 2009, 124, 499-505.

2. Mathur, A.; Singh, R.; Yousuf, S.; Bhardwaj, A.; Verma, S.K.; Babu, P.; Gupta, V.; Prasad, G.B.K.S.; Dua, V.K.Antifungal activity of some plant extracts against clinical pathogens. Adv. Appl. Sci. Res. 2011, 2, 260264.

3. Dubey, R.; Dubey, K.; Sridhar, C.; Jayaveera, K.N. Human vaginal pathogen inhibition studies on aqueous, methanolic and saponins extracts of stem barks of Ziziphusmauritiana. IJPSR 2011, 2, 659.

4. Lai, P.K.; Roy, J. Antimicrobial and chemopreventive properties of herbs and spices. Curr. Med. Chem. 2004, 11, 1451-1460.

5. Dubey, N.K.; Kumar, R.; Tripathi, P. Global promotion of herbal medicine: India's opportunity. Curr. Sci. 2004, 86, 37-41.

6. Kyung, K.H.; Fleming, H.P. S-Methyl-L-Cysteine sulfoxide as the precursor of methyl methanethiolsulfinate, the principal antibacterial compound in cabbage. J. Food Sci. 1994, 59, 350-355.

7. Hu, S.H.; Wang, J.C.; Kung, H.F.; Wang, J.T.; Lee, W.L.; Yang, Y.H. Antimicrobial effect of extracts of Cruciferous vegetables. Kaohsiung J. Med. Sci. 2004, 20, 591-599.

8. Ayaz, F.A.; Hayırlıglu-Ayaz, S.; Alpay-Karaoglu, S.; Grúz, J.; Valentová, K.; Ulrichová, J.; Strnad, M. Phenolic acid contents of kale (Brassica oleraceae L. var. acephala DC.) extracts and their antioxidant and antibacterial activities. Food Chem. 2008, 107, 19-25

9. Lynn, A.; Collins, A.; Fuller, Z.; Hillman, K.; Rateliffe, B. Cruciferous vegetables and colorectal cancer.Proc.Nutr. Soc. 2006, 65, 135-144.

10. El-Mowafy, E.M.; Maha, A. Treatment Effect of Red Cabbage and Cysteine against Paracetamol Induced Hepatotoxicity in Experimental Rats. J. Appl. Sci. Res. 2012, 8, 5852-5859.

11. Chauhan, E.S.; Tiwari, A.; Singh, A. Phytochemical screening of red cabbage (Brassica oleracea) powder and juice-A comparative study. J. Med. Plants Stud. 2016, 4, 196-199, ISSN 2320-3862.

12. Handa, S.S. Quality control and standardization of herbal material and traditional remedies. East Pharma 1995, 38, 23-25.

13. Sofowora, A. Medicinal Plants and Traditional Medicine in Africa; Spectrum Books: Ibadan, Nigeria, 1931.

14. Trease, G.E.; Evans, W.C. Pharmacognsy, 11th ed.; Brailliae Tiridal Can; Macmill and Publishers: London, UK, 1989.

15. Harborne, J.B. Phytochemical Methods; Chapman and Hall Ltd.: London, UK, 1973; pp. 49-188.

16. Gogo, L.A.; Shitandi, A.A.; Lokuruka, M.N.I.; Sang, W. Antimicrobial Effect of Juice Extract from Fermented Cabbage Against Select Food-Borne Bacterial Pathogens. J. Appl. Sci. Res. 2010, 6, 1807-1813. 